\title{
Agriculture in Manitoba: Compiling a Bibliography
}

\author{
Judy Harper .
}

AGRICULTURE HAS ALWAYS PROVIDED A VITAL ECONOMIC BASE FOR THE province of Manitoba. In I88 I the number of farms in Manitoba has been estimated at 9,077. This figure increased until I94 I when there were 58,024 farms in the province. In 1976 there were 32, I04 farms operating over I9 million acres. During this same time period Manitoba's population has increased from 62,260 in I $88 \mathrm{I}$ to $\mathrm{I}, 02 \mathrm{I}, 506$ in $1976 .{ }^{\mathrm{I}}$ Wheat production has been the largest single item in the agricultural economy of the province throughout the last century. Flaxseed, sunflowers, and canola (formerly called rapeseed) are also grown, as well as special crops such as buckwheat and field peas. Cattle, hogs, and poultry are also important commodities. Farm cash receipts in I980 totalled I.4 billion dollars from crop and livestock sales. $^{2}$

Over the years, agricultural education has continued to play an important role in the development of agriculture in Manitoba. The Manitoba Agricultural College was established in 1906 and was operated by the Manitoba Ministry of Agriculture until I 924 when it became the Faculty of Agriculture and Home Economics at the University of Manitoba. Initially there were eighty-five students enrolled in the Manitoba Agricultural College. ${ }^{3}$ Today the Faculty of Agriculture at the University of Manitoba receives research support by way of research grants, contracts, and special funds, of almost 4 million dollars annually. World famous for their research on triticale and canola, they also perform research in the areas of soils, crops, forages, horticulture, livestock, feeds, machinery, buildings, marketing, production economics, farm management, insects, food processing, and so on. Over one hundred faculty members are employed in the departments of Agricultural Economics, Animal Science, Entomology, Food Science, and Soil Science within the Faculty of Agriculture. Students work towards a four year Bachelor of Science in Agriculture degree or may opt for a two year Diploma offered by the School of Agriculture. Presently there are over two

The text of this paper was given at the 38 th Annual Meeting of the Bibliographical Society of Canada at Winnipeg, Manitoba, on June I 5 I 983. 
hundred and fifty graduate students enrolled in both the Masters and Doctoral programs in agriculture. The Faculty of Agriculture is also involved with extension and continuing education.

I have held the position of Librarian in the Agriculture Library at the University of Manitoba for the last five years. Soon after my arrival, I realized that more than half of the reference questions asked in the Agriculture Library pertained to some aspect of agriculture in Manitoba. Patrons sought information on such topics as 'the fruit, flowers, or vegetables which grow in Churchill, Manitoba,' or 'crop insurance in Manitoba,' or 'wild rice in Manitoba.' Students and faculty members from disciplines other than agriculture, such as Geography, History, and Natural Resources, sought information on Manitoba agriculture as well. This type of regional query had occurred much less frequently when I had worked in the Science Library, reflecting, I think, the different emphasis of the research and interests of the two faculties.

The field of agriculture has a number of excellent reference tools. Bibliography of Agriculture and all of the numerous Commonwealth Agricultural Bureaux abstracting publications provide extensive international coverage in agriculture. However, manually trying to find anything about Manitoba agriculture listed in these sources proved difficult and timeconsuming. Neither source indexes by geographical subdivision, so one must sift through numerous articles on a particular topic hoping to find one about Manitoba. Needless to say, the number of articles written specifically about a Manitoba topic in any year is comparatively small when searching at an international level. Government publications and theses are two other important sources of information dealing with Manitoba agriculture, however, these are indexed in a different index or not at all. While it is possible to search both Bibliography of Agriculture and the Commonwealth Agricultural Bureaux abstracts online through Dialog, by geographical location, this is not always feasible. Retrospective coverage begins with I970 for Bibliography of Agriculture and 1972 for Commonwealth Agricultural Bureaux abstracts. At the University of Manitoba, computer literature searches are offered on a cost recovery basis. Not all users are willing to pay for a literature search. Consequently both library users and Agriculture Library staff were spending a lot of time and experiencing a great deal of frustration while achieving only limited success when seeking information dealing with agriculture in Manitoba.

With these factors in mind, I decided that compiling a bibliography of agriculture pertaining specifically to Manitoba would be a worthwhile endeavour. I applied for, and was granted, a six month study leave from the University of Manitoba to work on this project. When I began my research I did not expect to find the number of items that I have (over 5,000 references 
to date); the problem had been to identify any reference at all on the topic!

I tried to approach the compilation of this bibliography in a logical manner. Initially I sought reference material on compiling bibliographies. One of the sources I found most helpful was A.M.L. Robinson's Systematic Bibliography, 4th ed., (London: Clive Bingley, 1979). Another excellent work was the U.S. Department of Agriculture's Miscellaneous Publication No. I4I4, Guidelines for the Preparation of Bibliographies, I982.

I decided that in order to be included in the bibliography an item had to cover an aspect of agriculture dealing directly with Manitoba, or Manitoba as part of the Canadian prairies: the fact that an experiment took place in the province was not always a criterion for inclusion. I included as many areas of Manitoba agriculture as possible. References with the word Manitoba in the title were relatively easy to select. Others generalizing into the prairies or western Canada were more carefully scrutinized to ensure they dealt with Manitoba. Ideally I would like to have included everything published fitting my criteria. Realistically, I soon realized that it would be virtually impossible to achieve this goal, certainly within the time frame I had been allotted. I decided to stress accuracy of the citation and availability of the references included. Only published works were included, and I have seen approximately 95 percent of the items cited. The remainder have been verified in the appropriate indexes. I decided that each reference would be cited in full. While abbreviating periodical titles has been the accepted practice for many years, I do not feel that this is the best approach for the user. The Commonwealth Agricultural Bureaux abstracts cite full titles and I agree with this approach.

While it was relatively easy to identify journals which might contain articles relating to agriculture in Manitoba (for example, Canadian Journal of Plant Science, Canadian Journal of Soil Science, Proceedings of the Entomological Society of Manitoba), I found it very time-consuming to go through these items. If I was fortunate, there was an annual index to each volume with a title index which I could scan; but annual subject indexes were not reliable because they usually did not index by location. Once an item was selected, I then checked the references hoping that the author had cited other similar works. Although it is standard practice in many of the sciences to leave out the titles of references cited, I was pleased that this is not the case in the field of agriculture. I relied quite heavily on citations from pertinent articles, especially to items published in journals which I could not scan cover to cover.

Theses from the University of Manitoba Faculty of Agriculture are a very important source of information about agriculture in Manitoba, one that is often overlooked by patrons searching for information on a particular topic. While the theses themselves were very important inclusions in my 
bibliography, their bibliographies, in-depth reviews of the subject, proved invaluable, especially to more obscure references. Also government publications contain a wealth of information on agriculture. I included the Manitoba Department of Agriculture publications as well as Canada Department of Agriculture publications dealing directly with Manitoba. I also included appropriate publications from other government departments.

I ran an on-line search through Dialog on the Agricola (i.e., Bibliography of Agriculture) database. This database, covering I970 to the present, provided approximately 600 references when the single term 'Manitoba' was searched. I felt this was the best search tactic and that it worked well since Agricola is an agricultural database. This computer search served as an excellent double-check for references I had already obtained, as well as a means of identifying additional items.

The bibliography is arranged by subject with an author index. Initially I had planned to use the book Agriculture Terms: as Used in the Bibliography of Agriculture, 2nd ed., I968, as a source for subject headings. However, I soon decided to set up my own authority file of subject headings and this has worked well. Most of the items in the bibliography were assigned one subject heading only; occasionally this was impossible and I assigned a second heading.

The actual mechanics of my work consisted of generating an author entry on a three by five slip consisting of the full citation in the correct format; the subject heading was assigned with the item in hand. At this time I also double-checked all the information if it had been initially taken from a citation. Next the subject card was typed on a three by five card, again containing full information. Thus I generated two files. The author file was essential to prevent duplication. I decided to concentrate on the period I933-I982, and am currently busy preparing these cards for entry on a word processor and for ultimate publication.

As I mentioned previously, I was extremely surprised at the number of references I actually found when I approached the project in a logical manner. I feel that the need for regional bibliographies is emphasized by the fact that so much information really does exist and yet cannot be located by normal means without spending a great deal of time and effort searching. There are, no doubt, areas of information other than agriculture in Manitoba which are just as hard to identify, and because we are living in the province of Manitoba, it is important to obtain this information. In agriculture, I found that certain disciplines are more thoroughly covered than others. I identified a large number of references in the areas of Soil Science, Entomology, and Plant Science, while references in Food Science and Animal Science were more limited. In retrospect this is to be expected.

In the process of compiling my bibliography I have become much more 
familiar with the development of agriculture and agricultural research in Manitoba. Key individuals in the history of agriculture in Manitoba such as Norman Criddle, Stuart Criddle, F.L. Skinner, A.V. Michener, and J.H. Ellis are no longer simply names. Their numerous written contributions to the field of agriculture in Manitoba are evidence of their importance.

The ultimate aim for anyone compiling a bibliography is publication. Certainly this is my objective. However, over the past three years this bibliography has become an integral part of the Agriculture Library at the University of Manitoba. It has proven its usefulness repeatedly. We are now able to answer the Manitoba-oriented reference questions, which used to be a problem, in a very positive manner and with a minimum of effort, providing better reference service to our patrons.

NOTES

I 100 Years of Agriculture in Manitoba, I88I-I980, a Statistical Profile (n.p.: Manitoba Agriculture, n.d.), p. 9.

2 Ibid., p. I07.

3 75th Anniversary, 1906-1981 and Growing for Tomorrow (Winnipeg, Manitoba: University of Manitoba, Faculty of Agriculture, I98I), p. 5. 